\title{
Bivalve Fishery of Sindhudurg and Ratnagiri Coast, Maharashtra, India
}

\author{
Santosh Nagnath Bhendekar ${ }^{* *}$, Vaibhav Dinkar Mhatre ${ }^{\dagger}$, Geetha Sasikumar ${ }^{\dagger \dagger}$, Kolliyil Sunil Mohamed ${ }^{\ddagger}$, \\ and Anulekshmi Chellappan ${ }^{\dagger}$ \\ ${ }^{\dagger}$ Mumbai Research Centre of ICAR- \\ Central Marine Fisheries Research \\ Institute, Mumbai, Maharashtra, India \\ ${ }^{\dagger}$ Mangalore Research Centre of ICAR- \\ Central Marine Fisheries Research \\ Institute, Mangalore, Karnataka, India
ICAR-Central Marine Fisheries Research Institute Kochi, Kerala India \\ www.cerf-jcr.org
}

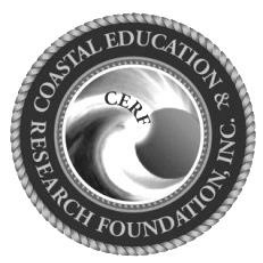

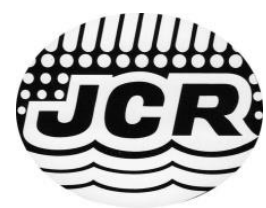

www.JCRonline.org

\begin{abstract}
Bhendekar, S.N.; Mhatre, V.D.; Sasikumar, G.; Mohamed, K.S., and Chellappan, A., 2019. Bivalve fishery of Sindhudurg and Ratnagiri coast, Maharashtra, India. In: Jithendran, K.P.; Saraswathy, R.; Balasubramanian, C.P.; Kumaraguru Vasagam, K.P.; Jayasankar, V.; Raghavan, R.; Alavandi, S.V., and Vijayan, K.K. (eds.), BRAQCON 2019: World Brackishwater Aquaculture Conference. Journal of Coastal Research, Special Issue No. 86, pp. 255-
\end{abstract} 257. Coconut Creek (Florida), ISSN 0749-0208.

Estimated bivalve landing of Maharashtra was 1,237 $\mathrm{t}$ in 2017. Oysters dominated the fishery (79\%) followed by clams (17\%) and mussel (4\%). The Indian rock oyster, Saccostrea cucullata locally known as 'Kalva' contributed $90 \%$ to the oyster catch. The fishery was observed mainly in Sindhudurg and Ratnagiri Districts. Clam landing comprised of Meretrix meretrix (44\%), M. casta (30\%), Paphia malabarica (18\%), Katelysia opima (7\%) and Polymedosa erosa (1\%). Green mussels (Perna viridis) were harvested along the coastal waters of Ratnagiri. Meretrix meretrix showed dominance in all month followed by $M$. casta and $P$. malabarica. Catch per unit efforts for clams and oyster were highest during June and July month. There was good demand for bivalves in local markets during the mechanised fishing ban period. Mostly women were handpicking the clams during low tide. There was good demand for bivalves in local markets during the mechanised fishing ban period (June-July). The correlation matrix shows condition index and percentage edibility correlated with the water temperature in the creek.

ADDITIONAL INDEX WORDS: Bivalve fishery, creek, condition index and percentage edibility, temperature.

\section{INTRODUCTION}

Bivalves are commercially important molluscs belonging to the class Bivalvia, that have laterally compressed bodies enclosed by a shell consisting of two hinged parts with extensive mantle lobes which secrete a single shell composed of two valves. Bivalves are reported to have originated in the euryhaline warm shallow coastal waters prior to their gradual invasion to estuarine, brackish, fresh and all the reaches of marine ecosystems. Out of the 652 species of marine bivalves that are reported from India, 88 species are endemic to Indian waters (Mohamed and Sasikumar, 2016). A variety of clam, mussel and oyster resources are distributed along Maharashtra coast, especially in Ratnagiri and Sindhudurg district. In the paucity of reliable data on bivalve landing estimates, the planning, regulatory and certification measure for conservation and effective utilization is difficult. The present study aims to estimate the bivalve landing in the major creeks of Sindhudurg and Ratnagiri districts of Maharashtra state along with the water quality affecting the condition index and percentage edibility.

\section{METHODS}

Data on monthly bivalve catch ( $\mathrm{kg}$ ), efforts (men/day) from January to December 2017 were collected from eight major

DOI: 10.2112/ SI86-037.1 received 6 March 2019; accepted in revision 31 May 2019.

*Corresponding author: santucofs@gmail.com

${ }^{\oplus}$ Coastal Education and Research Foundation, Inc. 2019 creeks of Ratnagiri and Sindhudurg district viz. Sakhartar, Shirgao, Mirya, Rahiwada and Bhatiye creek from Ratnagiri and Wadatar-Malai and Taramumbri creek from Sindhudurg district of Maharashtra as shown in Figure 1. The physico-chemical parameters such as temperature $\left({ }^{\circ} \mathrm{C}\right)$, salinity $(\%)$ and $\mathrm{pH}$ of water were recorded onsite using a mercury-in-glass thermometer, a refractometer (ERMA, Tokyo) and digital $\mathrm{pH}$ meter (Hanna Instruments, India) respectively. For the estimations of dissolved oxygen, (DO in $\mathrm{mg} \mathrm{L}^{-1}$ ) standard method described in APHA (2005) was used.

For the estimation of condition index or degree of fatness, about 265 specimens of Paphia malabarica in size range of 23.46-51.66 mm was examined monthly from May 2017 to December 2017 from Sakhartar creek of Ratnagiri. After the wet flesh weight of the clam was taken, the meat was kept in a hot air oven at $70^{\circ} \mathrm{C}$ for $24 \mathrm{hrs}$ and then dry weight taken. To calculate the condition index, the method given by Rajapandian and Rajan (1983) based on dry weight and shell cavity volume was used. The condition factor was calculated using the following mathematical equation:

$$
\text { Condition index }=\frac{\text { Weight of dry meat }}{\text { Volume of shell cavity }} \times 1000
$$

The quality of $P$. malabarica meat is known to undergo seasonal variation as the clams pass through various physiological phases due to feeding, maturation, spawning and recovery. Percentage edibility indicates the percentage of the 
ratio of wet meat weight to the whole weight of the clam. Percentage edibility was estimated by adopting the method given by Venkataraman and Chari (1951). Percentage edibility was calculated as follows:

$$
\text { Percentage edibility }=\frac{\text { Wet meat weight }}{\text { Total weight with shell }} \times 100
$$

The pair plot of condition index and percentage edibility of P. malabarica was plotted using Rstudio 1.1.456.
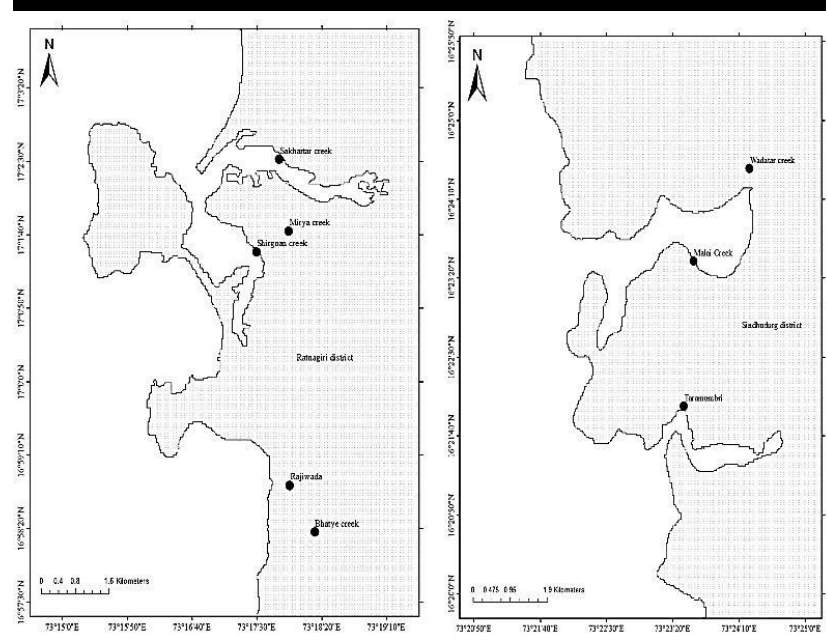

Figure 1. Creeks in Ratnagiri and Sindhudurg district of Maharashtra.

\section{RESULT}

Estimated bivalve landing of Maharashtra was $1,237 \mathrm{t}$ in 2017. Oysters dominated the fishery $(79 \%)$ followed by clams $(17 \%)$ and mussel (4\%). The Indian rock oyster, Saccostrea cucullata contributed $90 \%$ to the oyster catch (Figure 2). Catch and efforts of oyster fisheries showed two peaks; first from January to March and second during June-July. Clam landing comprised of Meretrix meretrix (44\%), M. casta (30\%), P. malabarica (18\%), Katelysia opima (7\%) and Polymedosa erosa (1\%). Meretrix meretrix showed dominance in all month, followed by $M$. casta and $P$. malabarica (Figure 3 ).

Green mussels (Perna viridis) were harvested along the coastal waters off Ratnagiri (Figure 4). At Rajiwada, fishers harvested green mussel using wooden and fibre canoe. There is good demand for bivalves in local markets during the mechanised fishing ban period (June-July) along the west coast of India, hence peak catch and effort for all bivalve groups were observed during June-July months. Mostly women handpicked the clams during low tide.

The influence of environmental parameters [sea surface temperature (SST), salinity, dissolved oxygen (DO) and $\mathrm{pH}$ ] on the condition indices and percentage edibility of the $P$. malabarica was analyzed. The highest condition index values (37.97) were recorded during the July month at temperature $31^{\circ} \mathrm{C}$ and percentage edibility (19.31) during October month at a temperature of $31.8^{\circ} \mathrm{C}$ in size range of $27-32 \mathrm{~mm}$. Pair plot revealed that the condition index and percentage edibility were correlated mainly with temperature and to a lesser extent with $\mathrm{pH}$ and dissolved oxygen.

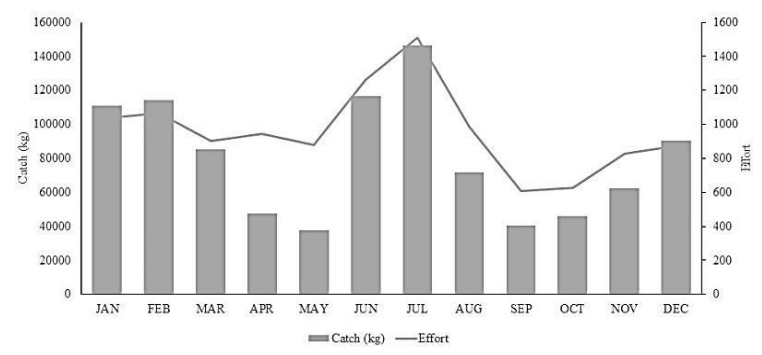

Figure 2. Oyster landing in Maharashtra during 2017.

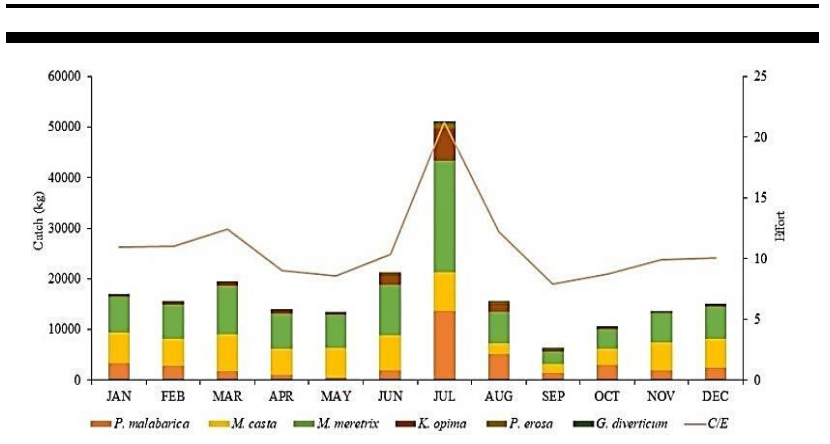

Figure 3. Clam landing in Maharashtra during 2017.

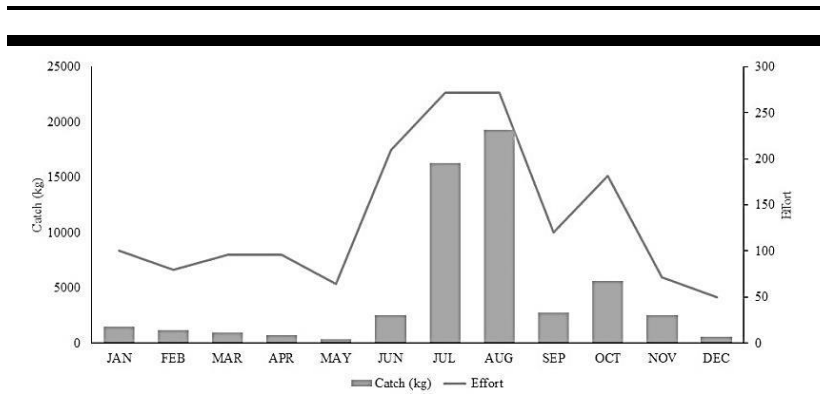

Figure 4. Green mussel landing in Maharashtra during 2017.

Absolute DO concentrations were low and presented a negative correlation with the condition index values, though this correlation was less pronounced than that of temperature (Figure 5). In Figure 5, the number below the diagonal is (absolute) correlation coefficients. The font size of the cross-correlation is proportional to its strength. The lines in the upper diagonal panels are smoothers.

\section{DISCUSSION}

Ranade (1964) surveyed the clam fishery of Maharashtra and found that the fishery is mainly dependent on three species of clams, namely, M. meretrix, K. opima and P. laterisulca forming nearly $90 \%$ of the total clam catch landed annually in the State. Similar observations were made by Mane (1973) and found that twelve creeks of clam beds produce about 80 per cent 
of the total yield, and seven creeks are confined to Ratnagiri district. The present study revealed five creeks from Ratnagiri and three creeks from Sindhudurg contributing to commercial fisheries of Maharashtra while $M$. meretrix, M. casta, $P$. malabarica, K. opima forming a major chunk of clam fisheries. Mohite and Mohite (2008) found maximum average density during November, and better catch/effort was observed during March, April, June, August and October-December at Shirgao and Sakhartar creek of Ratnagiri. In Maharashtra, the Indian rock oyster, Saccostrea cucullate dominates the bivalve landing (Mohamed and Sasikumar, 2016).

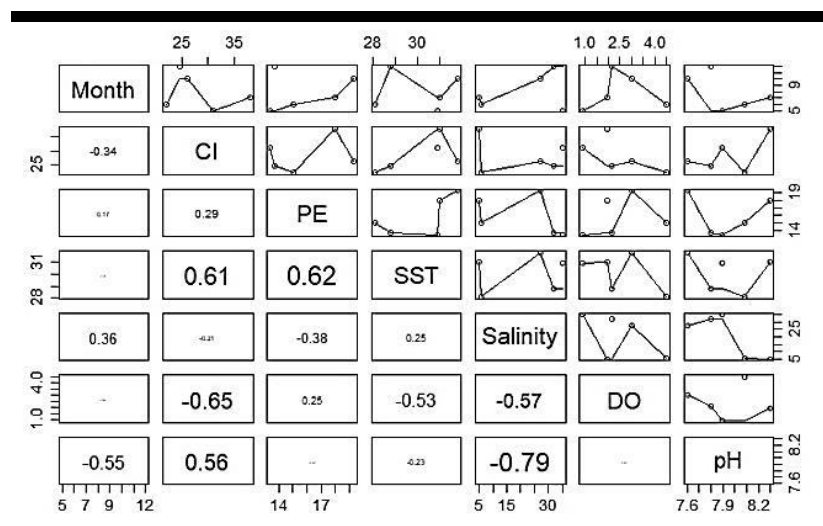

Figure 5. Pair plots of different physicochemical parameters with condition index and per cent edibility of Paphia malabarica.

In the present study, the highest value for condition index was recorded during July and percentage edibility in October. Condition index of $P$. malabarica showed an increasing trend, and the highest values were reported in September and higher percentage edibility during July at Shirgao and Bhatiye creek of Ratnagiri (Mohite, Mohite, and Singh, 2009). The quantity of meat in all the clams is relatively more during summer (Gangan et al., 2013). The highest value of 30.67 percentage edibility was recorded during June from Ratnagiri waters for M. meretrix (Sawant and Mohite, 2013). The condition index was taken as high if the values were above 14 (Appukuttan, 1996). In the present study, condition index value varied from 22.08-37.97 indicating good meat quality.

\section{CONCLUSION}

Bivalve landing estimates will help to aid planning, regulatory and certification measures for conservation and effective utilization of the resources in the region. Monthly catch and effort reveals trends in the exploitation status of bivalves in different seasons of the year. Correlation study of physicochemical parameters and condition index provides good insight on environmental changes affecting meat quality of $P$. malabarica.

\section{ACKNOWLEDGMENTS}

The authors gratefully acknowledge the constant support, facilities and motivation rendered by the Director, ICAR-Central Marine Fisheries Research Institute, Kochi (India).

\section{LITERATURE CITED}

American Public Health Association, and Andrew D.E., 2005. Standard methods for the examination of water and wastewater. Washington, D.C.: APHA-AWWA-WEF.

Appukuttan, K.K., 1996. Short neck calm fishery in Ashtamudi estuary. Seafood Export Journal, 27, 17-24.

Gangan, S.S.; Metar, S.Y.; Nirmale, V.H.; Chogale, N.D.; Balange, A.K.; Bhalekar, M.S., and Pai, R., 2013. Indigenous knowledge in the management of bivalve fishery of south Konkan coast of Maharashtra, India. Indian Journal of Traditional Knowledge, 12 (1), 72-79.

Mane, U.H., 1973. Studies on the biology, ecology and physiology of the marine clams. Bombay University, Ph.D. thesis, $300 \mathrm{p}$.

Mohamed, K.S. and Sasikumar, G., 2016. Overview of bivalve fisheries of India. In: Nandan, S.B.; Oliver, P.G.; Jayachandran, P.R., and Asha, C.V., Training manual - 1st International Training Workshop on Taxonomy of Bivalve Molluscs (Directorate of Public Relations and Publications, CUSAT, Kochi, India), pp. 47-53.

Mohite, S. and Mohite, A., 2008. Seasonal variations in the proximate composition of Paphia malabarica (Chemnitz) from estuarine regions of Ratnagiri, west coast of India. Geobios, 35 (2-3), 121-128.

Mohite, S.; Mohite, A., and Singh, H., 2009. On condition index and percentage edibility of the short neck clam Paphia malabarica (Chemintz) from estuarine regions of Ratnagiri, west coast of India. Aquaculture Research, 40, 69-73.

Rajapandian, M.E. and Rajan, C.T. 1983. Studies on the maturity stages and spawning periodicity of Crassostrea madrasensis (Preston) at Tuticorin bay. Proceedings of the Symposium on Coastal Aquaculture (Cochin, India), Paper 2, pp. 475-478.

Ranade, M.R., 1964. Studies in the biology, ecology and physiology of the marine clams. Bombay University, Ph.D. thesis, $266 \mathrm{p}$.

Sawant, P.P. and Mohite, S., 2013. Study of proximate composition of Meretrix meretrix (Linnaeus, 1758) of the Ratnagiri coast, Maharashtra, India. Biosciences Biotechnology Research Asia, 10 (1), 311-317.

Venkataraman, R. and Chari, S.D.T., 1951. Studies on oysters and clams-biochemical variations. Indian Journal of Medical Research, 39, 533-541. 